\title{
De partnerrelaties van mannelijke gedetineerden vóór detentie
}

Een vergelijkende studie tussen gedetineerden en de algemene bevolking ${ }^{l}$

Marieke van Schellen, Martijn Hogerbrugge, Paul Nieuwbeerta, Tanja van der Lippe \& Anja Dirkzwager

MEM 90 (2): 171-197

DOI: 10.1557/MEM2015.2.SCHE

\section{Summary \\ The partner relationships of male prisoners prior to incarceration \\ A comparative study between prisoners and the general population}

The current study examines the partner relationships of male prisoners prior to incarceration. Earlier studies on prisoners' partner relationships exclusively focused on the period during or after incarceration. However, knowledge on the pre-detention period is essential to establish any causal effects of incarceration on partner relationships. We describe a wide variety of aspects of prisoners' partner relationships: relationship history, current relationship status, and characteristics of the current relationship (quality, support, conflict, and partner violence). In addition, we make a direct comparison with partner relationships among the general population. We use unique data from the Prison Project $(N=1,909)$ and the Netherlands Kinship Panel Study (NKPS; $N=2,718$ ). The results show that prisoners' relationship histories are more instable, and characterized by less traditional relationship forms. Prior to imprisonment, partner relationships appear to be already more problematic. The findings stress the importance of including pre-detention partner relationship information in studies on the impact of incarceration. Also, they shed light on the potential role of justice officials in offering guidance on prisoners' partner relationships. 


\section{$1 \quad$ Inleiding}

Detentie is de meest ingrijpende strafrechtelijke sanctie die in Nederland kan worden opgelegd. De sanctie wordt steeds vaker toegepast, mede doordat het tegengaan van criminaliteit de afgelopen decennia steeds hoger op de politieke agenda is komen te staan. Het gaat in Nederland inmiddels om een omvangrijke gedetineerdenpopulatie - ook in vergelijking met andere Westerse landen (Dirkzwager, Nieuwbeerta \& Fiselier, 2009). Jaarlijks worden ongeveer 40.000 personen ingesloten, waarvan er ieder jaar 34.000 terugkeren in de samenleving (Dienst Justitiële Inrichtingen, 2013). Een van de doelen van gevangenisstraf is om daders af te houden van toekomstig crimineel gedrag (Dirkzwager e.a., 2009). Het blijkt echter dat veel exgedetineerden binnen twee jaar opnieuw worden veroordeeld (49\%) en dat 32 procent in die periode zelfs weer wordt ingesloten (Linckens \& De Looff, 2011).

Binnen de levensloopcriminologie wordt verondersteld dat deze recidivecijfers ten dele zijn toe te schrijven aan het feit dat detentie onbedoelde effecten kan hebben op het leven van gedetineerden. Een belangrijk onderdeel waarop deze effecten zichtbaar zouden zijn, zijn de partnerrelaties van gedetineerden (Dirkzwager e.a., 2009). Het idee dat een partnerrelatie ervoor zorgt dat delinquenten minder actief worden op crimineel gebied neemt bij deze verklaring voor recidive een prominente plaats in (Sampson \& Laub, 1993; Laub \& Sampson, 2003). Relatievorming zou er namelijk voor zorgen dat er een sociale binding ontstaat, waarbij partners elkaars gedrag controleren en hun relatie niet op het spel willen zetten door het plegen van delicten (Sampson \& Laub, 1993; Laub \& Sampson, 2003). Een partnerrelatie zou daarmee een weg kunnen vormen uit de criminaliteit. Dit zou vooral gelden als de bindingen tussen partners sterk zijn en de partner zelf niet crimineel actief is (Van Schellen, 2012). Als detentie de relatiekansen van gedetineerden vermindert en bestaande relaties ontwricht, is dus te verwachten dat detentie deels een averechts effect heeft op de recidivekans (Lopoo \& Western, 2005).

Voorgaand onderzoek bevestigt deze theoretische veronderstellingen ten dele. Zo hebben gedetineerden in de periode tijdens detentie veelal een kleinere kans om te trouwen en een grotere kans om te scheiden (Sampson \& Laub, 1993; London \& Parker, 2009; Sampson, Laub \& Wimer 2006; Van Schellen, 2012; Western, Lopoo \& McLanahan, 2004; Western, 2006; Western \& McLanahan, 200o). Voor de periode na detentie zijn de resultaten minder eenduidig. Zo vonden Lopoo en Western (2005) geen langetermijneffecten van detentie op partnerrelaties, terwijl de studies 
van Apel, Blokland, Nieuwbeerta en Van Schellen (2010) en Huebner (2005; 2007) wel blijvende effecten van detentie in de periode na vrijlating lieten zien.

Een probleem bij deze eerdere studies is echter dat zij zich uitsluitend hebben gericht op de periode tijdens of na detentie. Hierdoor is het lastig om vast te stellen of detentie daadwerkelijk een effect op partnerrelaties heeft: de relatie kon immers ook al slecht zijn vóór aanvang van de detentie. Als de situatie voor detentie niet adequaat wordt meegenomen, dan kan dit leiden tot een overschatting van de effecten van detentie (zie ook: Ramakers, Van Wilsum, Nieuwbeerta \& Dirkzwager, 2012). In tegenstelling tot de eerdere studies die de partnerrelaties van gedetineerden tijdens en na detentie bestudeerden, heeft dit onderzoek dan ook tot doel de partnerrelaties van gedetineerden in de periode vóór detentie te beschrijven. Hoewel er enkele kwalitatieve studies zijn die enig inzicht verschaffen in de partnerrelaties van gedetineerden vóór detentie, is onze studie - voor zover wij weten - de eerste die rapporteert over de partnerrelaties van een grootschalige steekproef van gedetineerden (in Nederland). Hierdoor zijn we beter in staat om algemene uitspraken te doen over de Nederlandse (en West-Europese) situatie. Bovendien zullen we niet alleen de huwelijksrelaties van gedetineerden bestuderen, maar ook andere relatievormen, zoals ongehuwd samenwonen - een relatievorm die door de groeiende incidentie onder de algehele bevolking ook steeds relevanter wordt in onderzoek naar de partnerrelaties van gedetineerden (Bersani, Laub \& Nieuwbeerta, 2009).

Om vast te kunnen stellen hoe de partnerrelaties van gedetineerden voor detentie zich verhouden, zal in deze studie een vergelijking worden gemaakt met de algemene Nederlandse bevolking. Omdat het merendeel van de gedetineerden in Nederland man is, zullen wij ons in onze beschrijving beperken tot mannelijke gedetineerden. De onderzoeksvraag van deze studie luidt hierdoor: Hoe zien de partnerrelaties van mannelijke Nederlandse gedetineerden voorafgaand aan detentie eruit en in hoeverre verschillen zij van de partnerrelaties van de mannelijke Nederlandse bevolking? We zullen hierbij uiteenlopende aspecten van de partnerrelaties van gedetineerden beschrijven: We gaan niet alleen in op de huidige relatiestatus (dat wil zeggen, vlak voor aanvang van de detentie), maar ook op de inhoud van deze relatie (zoals relatiekwaliteit, ervaren steun, conflicten en partnergeweld) en de eerdere relatiegeschiedenis. Allen zijn aspecten waarvan we op basis van de bestaande literatuur kunnen verwachten dat ze samenhangen met detentie of kunnen veranderen gedurende de detentieperiode (Gottfredson \& Hirschi, 1990; Sampson \& Laub, 1993). 
Om de onderzoeksvragen te beantwoorden wordt er gebruik gemaakt van twee grootschalige Nederlandse studies: het Prison Project en de Netherlands Kinship Panel Study (NKPS). Beide datasets bevatten unieke gegevens over de partnerrelaties van respectievelijk gedetineerden in voorlopige hechtenis en de algemene populatie. Voor het beantwoorden van de onderzoeksvraag zullen we niet alleen beschrijvende statistieken presenteren, maar ook multivariate regressieanalyses uitvoeren. Dit laatste doen we om te zien in hoeverre de kans op een bepaalde relatiestatus, relatiekenmerk, of de relatiegeschiedenis verschilt tussen gedetineerden en nietgedetineerden, wanneer gecontroleerd voor relevante achtergrondkenmerken. We zullen voor de multivariate analyses gebruik maken van lineaire, logistische en multinomiale regressie modellen.

\section{Eerdere studies naar de partnerrelaties van gedetineerden vóór detentie en mogelijke verklaringen voor verschillen met de algehele bevolking}

Studies naar de partnerrelaties van gedetineerden vóór detentie zijn schaars. Hoewel (kwantitatieve) registratiedata van justitie gegevens bevatten over de gehele gedetineerdenpopulatie, is er weinig bekend over de situatie waarin gedetineerden zich buiten de gevangenis bevinden. De focus ligt bij de registratiedata namelijk op de detentiesituatie en nazorg waarbij met name informatie over identiteitsdocumenten, inkomen, schulden, huisvesting en zorg de onderwerpen zijn die - in beperkte mate - aan de orde komen. Aan partnerrelaties wordt helaas geen aandacht besteed. Naast deze justitiële registratiedata bestaat er nog de tweejaarlijkse gedetineerdensurvey, die eveneens informatie bevat over een grote groep gedetineerden in Nederland $(N=6000)$. Hoewel deze survey wel enige informatie bevat over de situatie vóór detentie (waaronder het opleidingsniveau van gedetineerden), ontbreekt ook in dit geval informatie over partnerrelaties.

Om toch meer inzicht te krijgen in de partnerrelaties van gedetineerden vóór detentie richten we ons daarom tot een aantal kwalitatieve studies die verricht zijn op dit terrein. Hoewel de focus van deze kwalitatieve studies op de periode tijdens en na detentie ligt, geven zij eveneens enig inzicht in de periode daarvoor. Een aantal van deze studies laat zien dat partners door detentie de mogelijkheid krijgen om hun relatie te herstabiliseren en te verbeteren (Moerings, 1978; Comfort, 2008). Het algemene 
beeld dat echter naar voren komt is dat veranderingen in de kwaliteit van de relatie veelal negatief uitpakken. Met de relatie is het na detentie meestal slechter gesteld dan daarvoor (Van Baaren \& Van Son, 1984; Braman, 2004; Christian \& Kennedy, 2006; Harman, Smith \& Egan, 2007; Janssen, 1999). De resultaten van de kwalitatieve studies die specifieker ingaan op de periode voor detentie zijn gemengd. In het onderzoek van Janssen (1999) geeft het merendeel van de respondenten $(N=100)$ aan dat een (korte) detentie geen directe impact heeft op relatieontbinding. Er waren vaak voor die tijd al relatieproblemen en detentie vormde slechts een laatste druppel. Christian en Kennedy (2011) bekeken detentie vanuit de ogen van de partner van de gedetineerde $(N=14)$. De meeste partners zagen detentie slechts als een onderbreking en verwachtten dat de relatie weinig zou veranderen tijdens en na detentie. Daarbij moet opgemerkt worden dat het in dit onderzoek om relaties van een hoge kwaliteit ging. Deze relaties zouden als buffer kunnen dienen voor de eventuele negatieve effecten van detentie. Hoewel kwalitatieve studies meer inzicht geven in de situatie voor detentie, hebben zij als nadeel dat er kleine steekproeven zijn gebruikt. Bovendien is ook daar slechts geringe aandacht geweest voor de periode voorafgaand aan detentie. De bestaande kennis over de partnerrelaties van gedetineerden blijft daardoor uiteindelijk beperkt.

Toch zijn er uiteenlopende redenen om te verwachten dat gedetineerden voor hun daadwerkelijke detentie op het gebied van partnerrelaties verschillen van de algemene bevolking. Ten eerste kan een selectie-effect aan de verschillen ten grondslag liggen. Hiermee wordt bedoeld dat gedetineerden op diverse individuele kenmerken zouden kunnen afwijken van de algemene bevolking, zoals leeftijd, etniciteit, sociaaleconomische status en persoonlijkheidskenmerken. Deze individuele verschillen kunnen niet alleen de partnerrelaties beïnvloeden, maar ook de kans op detentie. Gottfredson en Hirschi (1990) wijzen bijvoorbeeld op het persoonlijkheidskenmerk 'zelfcontrole' als mogelijke achterliggende verklaring. Personen met een lage zelfcontrole zoeken onmiddellijke bevrediging van hun behoeftes, zijn impulsief, niet-verbaal en op de korte termijn gericht. Als gevolg hiervan zijn zij niet alleen meer geneigd om delicten te plegen, maar ook minder geneigd om bindingen aan te gaan met conventionele instituties, zoals het huwelijk (Hirschi \& Gottfredson, 1995). Als personen met een lage zelfcontrole een partnerrelatie aangaan, dan zou deze minder stabiel zijn en gekenmerkt worden door conflicten (Simons, Stewart, Gordon, Conger \& Elder, 2002). Ook zouden de verschillen in partnerrelaties tussen gedetineerden en de algemene bevol- 
king veroorzaakt kunnen worden doordat beide groepen simpelweg verschillen in relatievoorkeuren.

Ten tweede kan eerder justitieel contact eventuele verschillen tussen gedetineerden en de algemene bevolking verklaren. Veel gedetineerden hebben al eerder in detentie gezeten en vrijwel alle gedetineerden zijn eerder met justitie in aanraking geweest. Deze eerdere justitiële contacten kunnen de partnerrelatie van gedetineerden beïnvloeden, bijvoorbeeld via het stigma dat aan een strafblad en detentie verbonden is. Een stigma kan zorgen voor sociale en financiële stress en daarmee de kansen op een (stabiele) relatie verminderen. Specifiek voor detentie geldt dat daar nog een opsluitingeffect bij komt. Doordat gedetineerden afgesloten zijn van de samenleving, worden hun kansen om een potentiële partner te ontmoeten kleiner. Ook kan opsluiting eventuele bestaande partnerrelaties onder druk zetten, bijvoorbeeld omdat er gedurende die periode minder direct contact is tussen partners (Apel e.a., 2010; Lopoo \& Western, 2005; Pager, 2003; Van Schellen, 2012; Western, Lopoo \& McLanahan, 2004). Niet alleen hun voorkeuren, maar ook de mogelijkheden die (ex-)gedetineerden hebben op relatiegebied kunnen dus een impact hebben op hun (potentiële) partnerrelaties.

Ten derde kan een partnerrelatie van invloed zijn op wie er in de gevangenis terecht komt en wie niet. In hun informele sociale controle theorie wijzen Sampson en Laub (1993) erop dat het hebben van een (stabiele) relatie voor minder crimineel gedrag kan zorgen vanwege de sociale binding die erdoor ontstaat. Ook veranderingen in routine activiteiten en cognitieve transformaties (serieus worden), zouden aan deze afname in criminele activiteiten ten grondslag kunnen liggen (Warr, 1998; Giordano, Cernkovich \& Rudolph, 2002). Het ontbreken van een (stabiele) partnerrelatie zou kunnen verklaren waarom personen een delict hebben gepleegd en uiteindelijk in detentie terecht zijn gekomen.

Ten vierde zou het strafrechtsysteem een rol kunnen spelen bij eventuele verschillen in partnerrelaties tussen gedetineerden en de algemene bevolking. Er wordt wel gesuggereerd dat personen die een relatie hebben minder snel tot detentie worden veroordeeld dan personen die single zijn. Dit zou met name gelden als er kinderen in het spel zijn en detentie een nog grotere impact op het leven van de betrokken familieleden kan hebben (Johnson, Van Wingerden, \& Nieuwbeerta, 2010). Als onder gedetineerden minder vaak (stabiele) relaties voorkomen dan onder de algemene bevolking, dan kan dit veroorzaakt zijn doordat individuen (deels) selectief worden opgesloten.

De hierboven genoemde verklaringen kunnen we in de huidige studie 
helaas niet formeel toetsen, maar vormen wel de basis voor enkele keuzes in onze analyses. Allereerst zullen we binnen de gehele groep gedetineerden een driedeling maken: personen die niet eerder met justitie in aanraking zijn geweest, personen die eerder met justitie in aanraking zijn geweest maar niet eerder in detentie hebben gezeten en personen die al eerder in detentie hebben gezeten. Op deze manier kunnen we nagaan of degenen die al eerder in contact zijn geweest met justitie bijvoorbeeld vaker single zijn dan personen die voor het eerst worden gedetineerd. Daarnaast trachten we in de analyses zoveel mogelijk rekening te houden met mogelijke selectie-effecten door na te gaan in hoeverre eventuele verschillen in partnerrelaties terug te voeren zijn op verschillen in de opbouw van de verschillende groepen gedetineerden en de algemene bevolking. We zullen hierbij kijken naar leeftijd, etniciteit, opleidingsniveau, het hebben van een betaalde baan en het hebben van kinderen. Om meer inzicht te krijgen in de vraag of een bepaalde relatiestatus gewenst is of dat andere factoren - zoals beperkte mogelijkheden - een rol spelen, zullen we eveneens kijken naar de voorkeuren op het gebied van relatievorming. In de conclusie zullen we tenslotte dieper ingaan op de vraag hoe de resultaten van onze studie zijn te plaatsen binnen de hierboven besproken verklaringen.

\section{Data en methode}

\subsection{Gedetineerden}

Om de partnerrelaties van gedetineerden in kaart te brengen, maken we gebruik van data uit het Prison Project. Het Prison Project is een grootschalige longitudinale dataverzameling, waarin de bedoelde en onbedoelde effecten van detentie op het leven van gedetineerden en hun families worden onderzocht. Gedetineerden die in aanmerking kwamen voor het onderzoek waren mannen, in de leeftijd van 18 tot 65 jaar, geboren en legaal verblijvend in Nederland en die gedurende drie weken in voorlopige hechtenis zaten. ${ }^{2}$ Gedetineerden die niet in Nederland zijn geboren, zijn om verschillende redenen niet meegenomen in deze studie: zij verlaten vaak het land na hun detentie (en zijn dus moeilijk te volgen), ze hebben vaak taalproblemen en hun criminele geschiedenis is (deels) geregistreerd in het land van herkomst.

De huidige studie maakt gebruik van data uit de eerste meting. Deze meting vond plaats drie weken nadat de gedetineerde in het Huis van Bewaring was ingestroomd. Alle mannen die in de periode tussen oktober 
2010 en maart 2011 instroomden in een Nederlands Huis van Bewaring en aan bovengenoemde criteria voldeden zijn benaderd voor deelname. Van deze 3995 gedetineerden konden 2814 gedetineerden benaderd worden voor het onderzoek. De voornaamste reden dat gedetineerden niet benaderd konden worden was dat zij de inrichting al vroegtijdig hadden verlaten (82,8\% van de niet-benaderde gedetineerden). Van de 2814 gedetineerden die wel benaderd konden worden voor het onderzoek, hebben 1909 gedetineerden (68\%) daadwerkelijk deelgenomen aan het onderzoek, dat bestond uit een persoonlijk afgenomen enquête en zelf in te vullen schriftelijke vragenlijsten over henzelf en over een eventuele partner en kinderen. In totaal heeft $86 \%$ van de gedetineerden met een partner een vragenlijst ingevuld over hun partner.

Voor de analyses is er binnen de groep gedetineerden nog een onderscheid gemaakt tussen personen die niet eerder met justitie in aanraking zijn geweest, personen die eerder met justitie in aanraking zijn geweest maar niet eerder in detentie hebben gezeten en personen die al eerder in detentie hebben gezeten. ${ }^{3}$ De groep met eerder justitieel contact is voorafgaand aan het huidige verblijf in het Huis van Bewaring eerder gearresteerd door de politie, maar heeft niet eerder in detentie gezeten. De groep met eerdere detentie-ervaring heeft voorafgaand aan het huidige verblijf in het Huis van Bewaring eerder in jeugddetentie of in detentie voor volwassenen gezeten. Voor zowel arrestatie als (jeugd)detentie geldt dat dit een of meerdere keren eerder kan zijn gebeurd. Van de 1753 gedetineerden blijken er 212 (12,1 procent) geen eerder justitieel contact te hebben gehad, 338 gedetineerden (19,3 procent) al wel eerder justitieel contact te hebben gehad en 1077 (61,4 procent) al eerder in detentie te hebben gezeten. Van de overige 126 gedetineerden (7,2 procent) is het justitiële verleden onbekend. ${ }^{4}$

\subsection{Algemene bevolking}

Om de partnerrelaties van de algemene bevolking in kaart te brengen, maken we gebruik van de Netherlands Kinship Panel Study (NKPS; Dykstra, Kalmijn, Knijn, Komter, Liefbroer \& Mulder, 2005). Dit is een longitudinale studie naar de aard en sterkte van familiebanden in Nederland. In het kader van deze studie zijn gegevens verzameld onder een representatieve steekproef van de in Nederland verblijvende bevolking in de leeftijd van 18 tot 79 jaar. Het onderzoek is uitgevoerd in de periode 2002-2010 en bestaat uit drie meetmomenten. De hier gerapporteerde analyses zijn gebaseerd op de eerste meting die plaatsvond in de periode van oktober 2002 tot en met januari $2004(N=8161)$. Er is gekozen voor de eerste meting van 
de NKPS vanwege de hoogte van de respons en de selectieve uitval over tijd van respondenten met een slechte partnerrelatie. De NKPS-gegevens zijn verzameld aan de hand van persoonlijke interviews en schriftelijke vragenlijsten. Het betreft gedetailleerde informatie over de levenslopen van zowel de respondenten als hun familieleden. De respons was 45 procent: een percentage dat laag is in vergelijking met soortgelijke studies in het buitenland, maar vergelijkbaar is met grootschalige familieonderzoeken in $\mathrm{Ne}$ derland (Dykstra e.a., 2005).

De NKPS is uitermate geschikt als vergelijkingsgroep, omdat de studie in tegenstelling tot andere dataverzamelingen - informatie bevat over vele aspecten van partnerrelaties, waaronder de relatiegeschiedenis, de huidige relatiestatus ten tijde van het interview en de inhoud van de huidige relatie. Voor dit onderzoek gebruiken we een sub-sample van de NKPS waarbij dezelfde selectiecriteria zijn toegepast als in het Prison Project: alleen mannen in de leeftijd van 18 tot 65 jaar die in Nederland geboren zijn worden geanalyseerd. Dit resulteerde in een uiteindelijke steekproef van 2718 personen.

\subsection{Operationalisering}

\subsubsection{Relatiegeschiedenis}

In het Prison Project is aan de gedetineerden gevraagd hoeveel eerdere relaties zij hebben gehad - inclusief hun eventuele huidige relatie aan het begin van de detentie. Het gaat om relaties die tenminste 3 maanden hebben geduurd. Vervolgens moesten gedetineerden aangeven in hoeveel gevallen zij samengewoond hebben, getrouwd waren en officieel gescheiden zijn. Ook werd daarbij gevraagd naar het aantal partners waarvan men kinderen heeft. Bij het in kaart brengen van de relatiegeschiedenis is de huidige relatie buiten beschouwing gelaten.

In de NKPS is gevraagd of en hoe vaak respondenten in het verleden met een andere partner hebben samengewoond dan de huidige partner. Vervolgens is per ex-partner gevraagd of respondenten ooit met deze partner getrouwd zijn geweest. Per partner is gevraagd of ze uit elkaar zijn gegaan of dat de partner is overleden. Bij huwelijken is gevraagd of het een officiële scheiding betrof. Ook is gevraagd of de respondent kinderen met de ex-partner(s) heeft gekregen.

\subsubsection{Huidige relatie}

In beide databestanden is de huidige relatiestatus geoperationaliseerd als het hebben van een romantische relatie die een duur heeft van tenminste 
drie maanden. Daarbij is de respondent ook gevraagd of hij met zijn eventuele partner samenwoont en of hij getrouwd is met deze partner. Voor de gedetineerden gaat het om de situatie ten tijde van hun arrestatie. Voor de algemene bevolking gaat het om de situatie ten tijde van het interview in de periode 2002-2004. Naast de huidige relatiestatus is gevraagd naar het jaar waarin de respondent de relatie met deze partner heeft gekregen. Aangezien beide datasets informatie bevatten over de datum van deelname aan het onderzoek kon op deze manier de duur van de huidige relatie worden vastgesteld. Tevens is gevraag hoeveel gezamenlijke kinderen de respondent en huidige partner hebben.

Beide datasets bieden de mogelijkheid om meer inzicht te krijgen in de relatievoorkeuren van respondenten. In de NKPS is gevraagd of respondenten in de toekomst met een partner willen gaan samenleven (indien ze niet samenleven) en of ze in de toekomst willen trouwen (indien ze niet gehuwd zijn). De antwoordcategorieën bestonden uit 'ja', 'nee' en 'weet niet'. In het Prison Project is gevraagd hoe belangrijk gedetineerden het vinden om een partner te hebben (de antwoordcategorieën varieerden van 1 'helemaal niet belangrijk' tot 5 'heel belangrijk'). Daarnaast is gevraagd hoe graag (variërend van 1 'helemaal niet graag' tot 5 'heel graag') ze in de toekomst een relatie willen met een partner (indien ze geen partner hebben), hoe graag ze in de toekomst willen samenwonen met de huidige partner of toekomstige partner (indien ze niet samenwonen) en hoe graag ze willen trouwen met de huidige of toekomstige partner (indien ze niet getrouwd zijn).

\subsubsection{Inhoud huidige relatie}

In de analyses zal gekeken worden naar vier aspecten van de inhoud van de huidige partnerrelatie aan het begin van de detentie: kwaliteit, steun, conflicten en partnergeweld. Informatie over partnergeweld is alleen beschikbaar voor de gedetineerden. Bij de gedetineerden hebben de vragen betrekking op de situatie in de 12 maanden voorafgaan aan detentie. Bij de algemene bevolking betreft het de situatie in de 12 maanden voorafgaand aan het interview.

In het Prison Project wordt de kwaliteit van de relatie gemeten aan de hand van vier items, die samengevoegd zijn tot een schaal (Cronbachs' $\alpha$ $=0,91$ ): Hoe tevreden bent $\mathrm{u}$ over het algemeen met uw relatie ( 1 'helemaal niet tevreden' - 5 'heel erg tevreden')? Hoe is uw relatie vergeleken met die van anderen ( 1 'veel slechter' - 5 'veel beter')? Hoeveel geluk en voldoening haalt u uit uw relatie ( 1 'erg weinig' - 5 'erg veel')? Hoe is uw relatie vergeleken met een ideale relatie ( 1 'verre van ideaal' -5 'ideaal')? 
In de NKPS is de kwaliteit van de relatie gemeten met de volgende 4 stellingen (Cronbachs' $\alpha=0,95$ ): We hebben een goede relatie; De relatie met mijn partner maakt me gelukkig; Onze relatie is sterk; De relatie met mijn partner is erg stabiel ( 1 ' helemaal mee eens' - 5 'helemaal mee oneens'). Om een vergelijking te kunnen maken met de gedetineerden zijn de items omgecodeerd ( 1 'helemaal mee oneens' - 5 'helemaal mee eens'). ${ }^{5}$

De steun die ervaren wordt van de partner is zowel in het Prison Project (Cronbachs' $\alpha=0,87$ ) als de NKPS (Cronbachs' $\alpha=0,85$ ) met 5 items gemeten: In welke mate wordt $\mathrm{u}$ door uw partner gesteund bij: Beslissingen rond werk of opleiding; Zorgen of eventuele problemen met gezondheid; Besteding van vrije tijd en sociale contacten, allerlei praktische zaken en persoonlijke zaken die u bezighouden ( 1 'niet' - 4 'zeer veel').

Om conflicten binnen partnerrelaties in kaart te brengen is gedetineerden en NKPS-respondenten de volgende vraag gesteld: Kunt u van de volgende conflicten zeggen of zij wel eens zijn voorgekomen: Dat er felle discussies waren tussen u en uw partner; Dat de een de ander sterke verwijten maakte; Dat $\mathrm{u}$ een tijdje niet meer met elkaar hebt gepraat; Dat ruzies uit de hand liepen; Dat u een tijdje niet meer bij elkaar woonde? De antwoordcategorieën varieerden daarbij telkens van 7 'niet', 2 'een enkele keer' tot 3 'meerdere keren' (Prison: Cronbachs' $\alpha=0,81$; NKPS: Cronbachs' $\alpha=0,80)$.

Partnergeweld kon alleen voor de gedetineerden worden vastgesteld (Cronbach's $\alpha=0,84$ ). Gedetineerden is gevraagd of in de 12 maanden voor arrestatie de volgende zaken tussen hemzelf en de huidige partner waren voorgekomen: Ik gooide iets naar mijn partner dat hem / haar pijn deed; Mijn partner gooide iets naar mij dat mij pijn deed; Ik duwde mijn partner; Mijn partner duwde mij; Ik heb mijn partner geslagen of geschopt; Mijn partner heeft mij geslagen of geschopt; Ik bedreigde mijn partner met een mes of pistool; Mijn partner bedreigde mij met een mes of pistool ( 1 'niet', 2 'een enkele keer', 3 'meerdere keren'). In de analyses is partnergeweld niet alleen als schaal gebruikt, maar zijn ook dummy's geconstrueerd om vast te kunnen stellen in hoeverre de verschillende vormen van partnergeweld voorkomen. Hierbij zijn de items van gedetineerde en partner samengevoegd en de tweede en derde categorie samengenomen ( 1 'niet voorgekomen bij gedetineerde en partner' en 2 'wel voorgekomen bij gedetineerde en / of partner'). 


\subsection{Methode}

Het doel van deze beschrijvende studie is om vast te stellen in hoeverre de partnerrelaties van mannelijke gedetineerden vóór detentie verschillen van die van de rest van de mannen in Nederland. Alvorens dit te doen, hebben we gekeken in hoeverre de verschillen tussen de gedetineerden en de algemene populatie wellicht worden veroorzaakt door de compositieopbouw van beide groepen. Dat wil zeggen, in hoeverre de waargenomen verschillen worden veroorzaakt door verschillen in achtergrondkenmerken zoals leeftijd, etniciteit, het hebben van kinderen, opleidingsniveau en het hebben van een betaalde baan - kenmerken waarvan bekend is dat zij ook met partnerrelaties samenhangen (i.e, Spruijt \& Kormos, 2010; Verbruggen, Apel, Van der Geest \& Blokland, 2013).

Tabel 1 Achtergrondkenmerken van gedetineerden en de algemene bevolking ${ }^{\mathrm{a}}$

\begin{tabular}{|c|c|c|c|c|c|c|c|c|c|c|}
\hline \multirow[b]{3}{*}{ Leeftijd } & \multicolumn{8}{|c|}{ Gedetineerden } & \multicolumn{2}{|c|}{ Bevolking } \\
\hline & \multicolumn{2}{|c|}{$\begin{array}{c}\text { Nooit eerder } \\
\text { justitieel } \\
\text { contact }\end{array}$} & \multicolumn{2}{|c|}{$\begin{array}{l}\text { Eerder justi- } \\
\text { tieel contact }\end{array}$} & \multicolumn{2}{|c|}{$\begin{array}{c}\text { Eerder } \\
\text { gedetineerd }\end{array}$} & \multicolumn{2}{|c|}{ Totaal $^{c}$} & & \\
\hline & 33,5 & $(12,8)$ & 28,4 & $(10,1)$ & 31,6 & $(10,0)$ & 31,3 & $(10,6)$ & 43,3 & $(12,2)$ \\
\hline Allochtoon (\%) & 35,2 & & 38,5 & & 40,7 & & 39,6 & & 5,6 & \\
\hline Opleidingsniveau $(1-3)^{b}$ & 1,6 & $(0,7)$ & 1,5 & $(0,6)$ & 1,4 & $(0,5)$ & 1,4 & $(0,6)$ & 2,1 & $(0,8)$ \\
\hline Betaalde baan (\%) & 59,0 & & 47,5 & & 32,9 & & 39,2 & & 79,9 & \\
\hline Kinderen (\%) & 39,9 & & 31,6 & & 44,4 & & 41,4 & & 60,3 & \\
\hline
\end{tabular}

a Voor variabelen van ordinaal meetniveau of hoger wordt de standaarddeviatie tussen haakjes weergegeven. b De drie opleidingsniveaus die worden onderscheiden zijn: 'laag' (geen opleiding tot MAVO), 'midden' (MBO/ HAVO/VWO) en 'hoog' (HBO of hoger).

c In de totaalcategorie vallen ook gedetineerden waarvan het justitiële verleden onbekend is. Dit geldt ook voor alle overige tabellen.

BRON: NKPS, 2005; Prison Project, 2014.

Uit tabel 1 komt naar voren dat de gemiddelde leeftijd in de steekproef van gedetineerden ongeveer 12 jaar lager ligt dan in de steekproef van nietgedetineerden. In overeenstemming met de bijbehorende CBS-definitie, beschouwen we een persoon als allochtoon als één of beide ouders in het buitenland zijn geboren (tweedegeneratieallochtoon). De steekproef van gedetineerden blijkt voor een groter deel uit personen van allochtone afkomst te bestaan (39,6\% versus $5,6 \%)$. Verder is in de steekproef van gedetineerden het opleidingsniveau, het aantal personen met een betaalde baan of met kinderen lager. Dit laatste gegeven kan ook worden verklaard doordat de groep gedetineerden gemiddeld jonger zijn. Naast deze verschillen tussen de twee steekproeven, bestaan er ook binnen de groep ge- 
detineerden verschillen, waarbij degenen die nooit eerder justitieel contact hebben gehad het meest met de algemene bevolking overeen lijken te komen (met uitzondering van het hebben van kinderen). Gezien deze verschillen in compositie zullen we in de resultatensectie niet alleen beschrijvende statistieken presenteren, maar zal ook met behulp van multivariate regressieanalyses worden vastgesteld of verschillen in partnerrelaties blijven bestaan als gecontroleerd wordt voor de achtergrondkenmerken uit tabel 1 .

Om de analyses op zoveel mogelijk personen te kunnen baseren, zullen we voor de beschrijvende statistieken 'pairwise deletion' toepassen. Hierdoor verschilt de $N$ dus enigszins voor de verschillende variabelen (het maximale aantal missende waarden op een enkele variabele was 32,6\%). Omdat bij 'listwise deletion' het aantal te analyseren cases drastisch zou afnemen, hebben we voor de multivariate regressieanalyses gebruik gemaakt van multipele imputatie via de ICE (Imputation by Chained Equations) benadering in Stata 12.1. Op basis van de beschikbare data in de oorspronkelijke dataset zijn 100 andere datasets met geïmputeerde missende waarden gecreëerd, waarna de parameters van de verschillende regressiemodellen zijn berekend met behulp van de informatie in de geïmputeerde datasets (Royston, 2007).

\section{Resultaten}

\subsection{Relatiegeschiedenis}

In tabel 2 is de relatiegeschiedenis van gedetineerden en de algemene bevolking weergegeven - los van de eventuele huidige relatie. Er is gekeken naar eerdere samenwoonrelaties, eerdere huwelijken, eerdere scheidingen en eerdere partners waarvan men kinderen heeft. Voor gedetineerden was het eveneens mogelijk om eerdere relaties (van tenminste drie maanden) in kaart te brengen. Er is steeds vastgesteld of de desbetreffende 'relatiegebeurtenis' zich ooit heeft voorgedaan (maar de huidige relatie dus buiten beschouwing gelaten) en het aantal keer dat dit is gebeurd in het verleden. 
Tabel 2 Relatiegeschiedenis: eerdere relaties, eerdere samenwoonrelaties, eerdere huwelijken, eerdere scheidingen en eerdere partners waarvan kinderen ${ }^{a}$

\begin{tabular}{|c|c|c|c|c|c|c|c|c|c|c|}
\hline & \multicolumn{8}{|c|}{ Gedetineerden } & \multicolumn{2}{|c|}{ Bevolking } \\
\hline & \multicolumn{2}{|c|}{$\begin{array}{c}\text { Nooit eerder } \\
\text { justitieel } \\
\text { contact }\end{array}$} & \multicolumn{2}{|c|}{$\begin{array}{l}\text { Eerder justi- } \\
\text { tieel contact }\end{array}$} & \multicolumn{2}{|c|}{$\begin{array}{l}\text { Eerder gede- } \\
\text { tineerd }\end{array}$} & \multicolumn{2}{|c|}{ Totaal } & & \\
\hline Relatie: ooit (\%) & 86,8 & & 89,8 & & 91,8 & & 90,8 & & $-{ }^{b}$ & \\
\hline Relatie: \# & 2,8 & $(1,7)$ & 3,5 & $(4,2)$ & 4,8 & $(6,2)$ & 4,3 & $(5,5)$ & $-b$ & \\
\hline Samengewoond: ooit (\%) & 51,4 & & 50,7 & & 70,8 & & 64,2 & & 27,6 & \\
\hline Samengewoond: \# & 1,6 & $(0,9)$ & 1,5 & $(0,9)$ & 2,1 & $(1,6)$ & 2,0 & $(1,5)$ & 1,4 & $(0,7)$ \\
\hline Getrouwd: ooit (\%) & 35,2 & & 14,9 & & 16,9 & & 18,9 & & 56,1 & \\
\hline Getrouwd: \# & 1,2 & $(0,7)$ & 1,1 & $(0,4)$ & 1,1 & $(0,3)$ & 1,1 & $(0,4)$ & 1,1 & $(0,4)$ \\
\hline Gescheiden: ooit (\%) & 22,0 & & 10,0 & & 14,3 & & 14,6 & & 45,9 & \\
\hline Gescheiden: \# & 1,2 & $(0,7)$ & 1,4 & $(0,9)$ & 1,3 & $(0,7)$ & 1,3 & $(0,7)$ & 1,1 & $(0,4)$ \\
\hline $\begin{array}{l}\text { Partners waarvan } \\
\text { kinderen: ooit (\%) }\end{array}$ & 20,7 & & 16,9 & & 32,0 & & 28,0 & & 46,3 & \\
\hline $\begin{array}{l}\text { Partners waarvan } \\
\text { kinderen: \# }\end{array}$ & 1,2 & $(0,6)$ & 1,0 & $(0,1)$ & 1,3 & $(0,6)$ & 1,3 & $(0,6)$ & 1,1 & $(0,3)$ \\
\hline $\begin{array}{l}\text { oor variabelen van ordi } \\
\text { fformatie over eerdere } \\
\text { PS. }\end{array}$ & relati & . & $\pi$ & , & J & (1) & to & & . & de \\
\hline
\end{tabular}

Allereerst vergelijken we de groep gedetineerden als totaal met de algemene bevolking op relatiegebeurtenissen die ooit hebben plaatsgevonden. Het valt op dat gedetineerden vóór de huidige relatie relatief vaak ooit hebben samengewoond $(64,2 \%$ versus $27,6 \%)$ en relatief weinig ooit getrouwd te zijn geweest met een ex-partner (18,9\% versus $56,1 \%)$. Logischerwijs heeft onder de groep gedetineerden daarom ook minder vaak ooit een scheiding plaatsgevonden (14,6\% versus 45,9\%). Gedetineerden hebben relatief minder vaak ooit een relatie gehad waarbinnen kinderen zijn geboren $(28,0 \%$ versus $46,3 \%)$. Als we kijken naar het aantal keer dat een persoon een bepaalde relatievorm had, dan blijkt dat gedetineerden niet alleen vaker ooit hebben samengewoond, maar ook dat het aantal eerdere samenwoonrelaties hoger ligt dan onder de algemene bevolking (1,99 versus 1,38). Hoewel gedetineerden minder vaak ooit gescheiden zijn, valt op dat - als dit wél gebeurd is - het gemiddeld om meer scheidingen gaat dan onder de algemene bevolking $(1,3$ versus 1,1$)$. Hetzelfde geldt voor het gemiddelde aantal partners waarvan zij kinderen hebben $(1,3$ versus 1,1$)$.

Binnen de groep gedetineerden is een onderscheid gemaakt tussen personen die nooit eerder met justitie in aanraking zijn geweest, personen die eerder met justitie in aanraking zijn geweest maar niet eerder in detentie 
hebben gezeten en personen die al eerder in detentie hebben gezeten. De frequentie van samenwoonrelaties was bij alle drie de groepen hoger dan de frequentie van huwelijken. Wat verder opvalt is dat vooral de eerder gedetineerden gemiddeld vaker eerder hebben samengewoond en van gemiddeld meer partners kinderen hebben. Trouwen (en daarmee ook scheiden) blijkt in vergelijking met de twee andere groepen juist weer minder vaak voor te komen.

Om vast te stellen in hoeverre de gevonden resultaten blijven bestaan als er gecontroleerd wordt voor verschillen in achtergrondkenmerken tussen de onderscheiden groepen, zijn er een aantal regressieanalyses uitgevoerd. Voor de relatiegebeurtenissen die ooit plaats hebben kunnen vinden (ooit samengewoond, ooit getrouwd, ooit gescheiden en ooit kinderen met eerdere partner(s)) zijn logistische regressieanalyses uitgevoerd. Voor het aantal keer dat deze gebeurtenissen eerder hebben plaatsgevonden zijn Poisson-regressieanalyses uitgevoerd (vanwege het feit dat het numerieke afhankelijke variabelen betreffen). In tabel 3 zijn de resultaten gerapporteerd van de analyses waar groepsverschillen blijven bestaan na controle voor de achtergrondkenmerken: leeftijd, etniciteit, het hebben van kinderen, opleidingsniveau en het hebben van een betaalde baan. ${ }^{6}$ In tegenstelling tot wat tabel 2 deed vermoeden zijn er na controle voor de genoemde achtergrondkenmerken geen verschillen meer in het aantal eerdere scheidingen. De overige resultaten zijn wel in overeenstemming met de beschrijvende analyses. Vergeleken met de algemene bevolking hebben gedetineerden een grotere kans om ooit te hebben samengewoond - dat geldt voor alle onderscheiden groepen. Ook het aantal keer dat zij hebben samengewoond is bij vrijwel alle categorieën groter. Eerder gedetineerden hebben een kleinere kans om ooit eerder getrouwd te zijn geweest en logischerwijs ook om ooit gescheiden te zijn geweest.

Geconcludeerd kan worden dat gedetineerden - los van hun eventuele huidige relatie - een relatief instabiele relatiegeschiedenis kennen (groter aantal keer samengewoond, groter aantal eerdere partners waarvan kinderen). Bovendien kozen zij in hun levensloop vaker voor minder traditionele relatievormen (vaker samenwonend, minder vaak getrouwd). Dat laatste blijkt ook uit het feit dat vrijwel alle gedetineerden ooit een eerdere relatie (van tenminste 3 maanden) hebben gehad, waarin samenwonen of trouwen niet aan de orde was (90,8\%). 
Tabel 3 Relatiegeschiedenis: logistische regressieanalyses ooit samengewoond, ooit getrouwd, ooit gescheiden en poisson regressieanalyse aantal keer samengewoond ${ }^{a}$

\begin{tabular}{|c|c|c|c|c|c|c|c|c|}
\hline & \multicolumn{2}{|c|}{$\begin{array}{l}\text { Ooit samen- } \\
\text { gewoond }\end{array}$} & \multicolumn{2}{|c|}{$\begin{array}{c}\text { Aantal keer } \\
\text { samengewoond }\end{array}$} & \multicolumn{2}{|c|}{ Ooit getrouwd } & \multicolumn{2}{|c|}{ Ooit gescheiden } \\
\hline & B & S.E. & B & S.E. & B & S.E. & B & S.E. \\
\hline Intercept & $-2,83^{* * *}$ & 0,20 & $-0,32^{* *}$ & 0,11 & $-6,46^{* * *}$ & 0,46 & $3,37^{* * *}$ & 0,93 \\
\hline \multicolumn{9}{|l|}{ Groep (bevolking = ref.) } \\
\hline Nooit eerder contact & $1,49^{* * *}$ & 0,19 & $0,19^{*}$ & 0,10 & $-0,11$ & 0,32 & 1,14 & 0,75 \\
\hline Eerder justitieel contact & $1,75^{* * *}$ & 0,16 & $0,29^{* *}$ & 0,08 & $-0,55$ & 0,31 & 0,20 & 0,65 \\
\hline Eerder detentie & $2,45^{* * *}$ & 0,12 & $0,61^{* * *}$ & 0,06 & $-1,10^{* * *}$ & 0,21 & $1,72^{* *}$ & 0,56 \\
\hline Eerder onbekend & $2,35^{* * *}$ & 0,27 & $0,54^{* * *}$ & 0,13 & $-1,14^{*}$ & 0,54 & $-c$ & $-c$ \\
\hline Leeftijd & $0,04^{* * * *}$ & 0,00 & $0,01^{* * *}$ & 0,00 & $0,13^{* * *}$ & 0,01 & $-0,04^{* *}$ & 0,02 \\
\hline Allochtoon & $-0,43^{* * *}$ & 0,11 & $-0,06$ & 0,05 & 0,38 & 0,23 & $-0,09$ & 0,43 \\
\hline \multicolumn{9}{|c|}{ Opleidingsniveau (laag = ref.) } \\
\hline Midden & $-0,06$ & 0,09 & 0,02 & 0,05 & 0,01 & 0,17 & $-0,08$ & 0,28 \\
\hline Hoog & $-0,06$ & 0,10 & 0,00 & 0,06 & $-0,48^{*}$ & 0,20 & 0,52 & 0,31 \\
\hline Betaald werk & 0,04 & 0,08 & $-0,03$ & 0,04 & 0,04 & 0,17 & 0,31 & 0,27 \\
\hline Kinderen & 0,03 & 0,08 & 0,03 & 0,04 & $1,65^{* * *}$ & 0,16 & $0,06 * * *$ & 0,34 \\
\hline Minimale $N^{b}$ & \multicolumn{2}{|c|}{4258} & \multicolumn{2}{|c|}{1701} & \multicolumn{2}{|c|}{1701} & \multicolumn{2}{|c|}{625} \\
\hline
\end{tabular}

${ }^{*}=p<0,05 ;{ }^{* *}=p<0,01 ;{ }^{* * *}=p<0,001$

a De B-waarden voor ooit samengewoond / ooit getrouwd / ooit gescheiden representeren logistische regressie coëfficiënten. Deze coëfficiënten kunnen worden getransformeerd tot odds ratios door ze te exponentiëren $\left(e^{B}\right)$. b Omdat er gebruik is gemaakt van conditionele multipele imputatie, verschilt het aantal observaties in iedere geïmputeerde dataset. De gerapporteerde $N$ is het minimale aantal observaties in één geïmputeerde dataset. c Vanwege lege cellen in de cross-tabulatie tussen de afhankelijke variabele en de dummy variabele "Eerder onbekend", is deze dummy-variabele niet in de analyse opgenomen.

BRON: NKPS, 2005; Prison Project, 2014.

\subsection{Huidige relatie}

De vraag is of deze geschiedenis van minder stabiele en traditionele relatievormen ook is terug te zien in de relatie(status) van gedetineerden aan het begin van de detentieperiode. In deze paragraaf zal allereerst ingegaan worden op de huidige relatiestatus van gedetineerden. Vervolgens zal er worden ingegaan op de voorkeuren van de gedetineerden ten aanzien van partnerrelaties. Deze laatste analyses geven meer inzicht in een mogelijke missmatch tussen wat gedetineerden willen op relatiegebied en hoe de daadwerkelijke situatie is. 
Tabel 4 Huidige relatiestatus ${ }^{a}$

\begin{tabular}{|c|c|c|c|c|c|c|c|c|c|c|}
\hline & \multicolumn{8}{|c|}{ Gedetineerden } & \multicolumn{2}{|c|}{ Bevolking } \\
\hline & \multicolumn{2}{|c|}{$\begin{array}{c}\text { Nooit eerder } \\
\text { justitieel } \\
\text { contact }\end{array}$} & \multicolumn{2}{|c|}{$\begin{array}{l}\text { Eerder justi- } \\
\text { tieel contact }\end{array}$} & \multicolumn{2}{|c|}{$\begin{array}{c}\text { Eerder } \\
\text { gedetineerd }\end{array}$} & \multicolumn{2}{|c|}{ Totaal } & & \\
\hline Single (\%) & 35,7 & & 40,8 & & 40,3 & & 40,1 & & 26,4 & \\
\hline LAT-relatie (\%) & 28,6 & & 34,7 & & 31,0 & & 31,4 & & 7,9 & \\
\hline Samenwonend (\%) & 14,3 & & 15,3 & & 23,3 & & 20,4 & & 12,2 & \\
\hline Getrouwd (\%) & 21,4 & & 9,2 & & 5,3 & & 8,1 & & 53,7 & \\
\hline Duur huidige relatie (jaren) & 11,7 & $(11,1)$ & 5,4 & $(6,6)$ & 5,6 & $(6,3)$ & 6,4 & $(7,5)$ & 19,7 & $(13,2)$ \\
\hline $\begin{array}{l}\text { Aantal kinderen met } \\
\text { huidige partner }\end{array}$ & 1,9 & $(0,6)$ & 1,3 & $(1,5)$ & 1,4 & $(3,1)$ & 1,4 & $(2,6)$ & 1,5 & $(1,3)$ \\
\hline
\end{tabular}

a Voor variabelen van ordinaal meetniveau of hoger wordt de standaarddeviatie tussen haakjes weergegeven. Bron: NKPS, 2005; Prison Project, 2014.

In tabel 4 is de relatiestatus aan het begin van de detentie afgezet tegen die van de algemene bevolking. Het blijkt dat, ten tijde van hun arrestatie, gedetineerden relatief vaker single zijn dan de rest van de bevolking (40,1\% versus $26,4 \%$ ). Dit is opvallend aangezien tabel 2 liet zien dat relaties (van tenminste drie maanden) onder gedetineerden verre van ongewoon zijn. Als gedetineerden een relatie hebben dan blijkt het relatief vaak om een LAT-relatie te gaan $(31,4 \%$ versus $7,9 \%)$ of om een samenwoonrelatie $(20,3 \%$ versus $12,2 \%)$. Huwelijksrelaties komen daarentegen weinig voor $(8,1 \%$ versus $53,7 \%)$. Dit relatiepatroon is nog zichtbaarder voor de groep met eerder justitieel contact en vooral voor de groep met eerdere detentie. De groep met nooit eerder justitieel contact is daarentegen het meest vergelijkbaar met de algemene bevolking. Verder valt op dat de duur van de huidige relatie relatief kort is voor gedetineerden (6,4 versus 19,7 jaar). Hoewel gedetineerden gemiddeld jonger zijn dan de algemene bevolking, vormt dit geen volledige verklaring: ook binnen de groep gedetineerden zijn er grote verschillen in relatieduur. Er zijn geen duidelijke verschillen in het aantal kinderen dat men met de huidige partner heeft $(1,4$ versus $1,5)$. De groep gedetineerden zonder eerder justitieel contact heeft gemiddeld de meeste kinderen met de huidige partner $(1,9)$.

In tabel 5 is gekeken in hoeverre deze verschillen in huidige relatiestatus blijven bestaan als gecontroleerd wordt voor de individuele achtergrondkenmerken. Aangezien de afhankelijke variabele uit meerdere ongeordende categorieën bestaat (single, LAT-relatie, samenwonend, getrouwd) is een multinomiale regressieanalyse uitgevoerd. Om de resultaten van de multinomiale regressieanalyse eenvoudiger te kunnen interpreteren, presenteren we de uitkomsten van deze analyse als marginale effecten. 
Voordeel van het weergeven van marginale effecten is dat de kans op de verschillende relatie-statussen los van elkaar bekeken kan worden in plaats van in vergelijking tot elkaar (bijvoorbeeld single versus LAT-relatie) zoals bij multinomiale regressie gebruikelijk is. ${ }^{7}$

Tabel 5 Huidige relatiestatus: multinomiale regressieanalyse (marginale effecten) $(N=4400)^{a}$

\begin{tabular}{|c|c|c|c|c|c|c|c|c|}
\hline & \multicolumn{2}{|c|}{ Single } & \multicolumn{2}{|c|}{ LAT-relatie } & \multicolumn{2}{|c|}{ Samenwonend } & \multicolumn{2}{|c|}{ Getrouwd } \\
\hline & B & S.E. & B & S.E. & B & S.E. & B & S.E. \\
\hline \multicolumn{9}{|l|}{ Groep (bevolking = ref.) } \\
\hline Nooit eerder contact & $-0,03$ & 0,03 & $0,11^{* * *}$ & 0,02 & $0,05^{*}$ & 0,02 & $-0,14^{* * *}$ & 0,03 \\
\hline Eerder justitieel contact & 0,03 & 0,03 & $0,14^{* * *}$ & 0,02 & 0,04 & 0,02 & $-0,20^{* * *}$ & 0,03 \\
\hline Eerder detentie & $0,04^{*}$ & 0,02 & $0,14^{* * *}$ & 0,02 & $0,13^{* * *}$ & 0,02 & $-0,31^{* * *}$ & 0,02 \\
\hline Eerder onbekend & 0,06 & 0,04 & $0,11^{* * *}$ & 0,03 & $0,21^{* * *}$ & 0,03 & $-0,38^{* * *}$ & 0,06 \\
\hline Leeftijd & $0,00^{* * *}$ & 0,00 & $-0,00^{* * *}$ & 0,00 & $-0,00^{* * *}$ & 0,00 & $0,01^{* * *}$ & 0,00 \\
\hline Allochtoon & $-0,02$ & 0,02 & $0,06^{* * *}$ & 0,01 & $-0,02$ & 0,02 & $-0,02$ & 0,02 \\
\hline \multicolumn{9}{|c|}{ Opleidingsniveau (laag = ref,) } \\
\hline Midden & $-0,03^{*}$ & 0,01 & 0,01 & 0,01 & $-0,01$ & 0,01 & $0,03^{*}$ & 0,01 \\
\hline Hoog & $-0,14^{* * *}$ & 0,02 & $0,05^{* *}$ & 0,02 & $0,06^{* * *}$ & 0,02 & 0,02 & 0,01 \\
\hline Betaald werk & $-0,11^{* * *}$ & 0,01 & $-0,02$ & 0,01 & $0,04^{* *}$ & 0,01 & $0,09 * * *$ & 0,01 \\
\hline Kinderen & $-0,29 * * *$ & 0,01 & $-0,05 * * *$ & 0,01 & $0,07^{* * *}$ & 0,01 & $0,28^{* * *}$ & 0,01 \\
\hline
\end{tabular}

Uit tabel 5 blijkt dat de eerder gevonden verschillen in relatiestatus deels blijven bestaan. Vergeleken met de algemene bevolking hebben alle groepen gedetineerden een grotere kans om een LAT-relatie te hebben en een kleinere kans om getrouwd te zijn. Voor de kans om samen te wonen of om single te zijn blijken de resultaten minder eenduidig te zijn. Hoewel de kans dat iemand single is op het moment dat hij wordt gearresteerd toeneemt als die persoon eerder gedetineerd is geweest, is de effectgrootte en significantie van dit effect minimaal. Voor samenwoonrelaties blijkt deze kans voor eerder gedetineerden wel aanzienlijk te zijn. Hoewel de kans dat een gedetineerde een samenwoonrelatie heeft ten tijde van zijn arrestatie groter is wanneer zijn justitiële verleden onbekend is, lijkt dit een artefact te zijn van het geringe aantal cases dat in deze categorie valt.

De vraag rijst nu in hoeverre de gevonden verschillen in relatievormen ten tijde van de arrestatie veroorzaakt worden door 'afwijkende' relatievoorkeuren in de steekproef van gedetineerden. Tabel 6 biedt inzicht in de beantwoording van deze vraag. Allereerst blijkt dat gedetineerden het be- 
langrijk vinden om een partner te hebben: 79 procent geeft aan dit belangrijk of heel belangrijk te vinden. Tevens hebben gedetineerden een sterke relatiewens en samenwoonwens. Opvallend is dat de helft ook wenst te trouwen, terwijl in tabel 4 te zien was dat deze relatievorm onder gedetineerden relatief weinig voorkomt. De wens tot samenwonen en trouwen is bovendien sterker dan onder de algemene bevolking (75,8\% versus $62,3 \%$ en $50,3 \%$ versus $38,6 \%$ ). Wel is te zien dat de wens tot een bepaalde relatievorm minder sterk wordt naarmate de ernst van het criminele verleden toeneemt (eerder justitieel contact en met name eerdere detentie). De resultaten zijn in tegenspraak met het idee dat delinquenten geen vaste of traditionele relatievorm zouden willen aangaan. Het lijkt er eerder op dat ze er vanwege hun persoonlijke kenmerken minder goed toe in staat zijn of minder mogelijkheden daartoe hebben. ${ }^{8}$

Tabel 6 Relatievoorkeuren: percentage (heel) belangrijk, (heel) graag, of 'ja'

\begin{tabular}{|c|c|c|c|c|c|}
\hline & \multicolumn{4}{|c|}{ Gedetineerden } & \multirow[t]{2}{*}{ Bevolking } \\
\hline & $\begin{array}{l}\text { Nooit eerder } \\
\text { justitieel } \\
\text { contact }\end{array}$ & $\begin{array}{l}\text { Eerder justi- } \\
\text { tieel contact }\end{array}$ & $\begin{array}{l}\text { Eerder gede- } \\
\text { tineerd }\end{array}$ & Totaal & \\
\hline $\begin{array}{l}\text { Belangrijk om partner te } \\
\text { hebben }(\%)\end{array}$ & 82,8 & 78,1 & 78,6 & 78,7 & $-{ }^{a}$ \\
\hline Relatiewens (\%) & 81,0 & 78,9 & 74,8 & 76,1 & $-{ }^{a}$ \\
\hline Samenwoonwens (\%) & 82,9 & 77,7 & 73,6 & 75,8 & 62,3 \\
\hline Trouwwens $(\%)^{b}$ & 53,6 & 50,8 & 49,2 & 50,3 & 38,6 \\
\hline \multicolumn{6}{|c|}{$\begin{array}{l}\text { a Deze informatie ontbreekt in de NKPS. } \\
\text { b Voor gedetineerden betreft het 5-puntsschalen; voor de algemene bevolking } 3 \text { categorieën: ja / nee / weet niet. } \\
\text { Bron: NKPS, 2005; Prison Project } 2014 \text {. }\end{array}$} \\
\hline
\end{tabular}

\subsection{Inhoud huidige relatie}

De voorgaande beschrijvingen en analyses zeggen ons echter niets over de inhoud van de huidige partnerrelatie. Voor zowel de algemene bevolking als de gedetineerden hebben we daarom naar drie relatiekenmerken gekeken: kwaliteit, steun en conflict. Voor gedetineerden was er bovendien informatie beschikbaar over mogelijk geweld van de partner richting de gedetineerden. 
Tabel 7 Inhoud huidige relatie: kwaliteit, steun, conflict en partnergeweld

\begin{tabular}{|c|c|c|c|c|c|c|c|c|c|c|}
\hline \multirow[b]{3}{*}{ Kwaliteit Prison (1-5) } & \multicolumn{8}{|c|}{ Gedetineerden } & \multicolumn{2}{|c|}{ Bevolking } \\
\hline & \multicolumn{2}{|c|}{$\begin{array}{c}\text { Nooit eerder } \\
\text { justitieel } \\
\text { contact }\end{array}$} & \multicolumn{2}{|c|}{$\begin{array}{l}\text { Eerder justi- } \\
\text { tieel contact }\end{array}$} & \multicolumn{2}{|c|}{$\begin{array}{c}\text { Eerder } \\
\text { gedetineerd }\end{array}$} & \multicolumn{2}{|c|}{ Totaal } & & \\
\hline & 4,2 & $(1,0)$ & 4,3 & $(0,9)$ & 4,1 & $(0,9)$ & 4,2 & $(0,9)$ & & \\
\hline Kwaliteit NKPS (1-5) & & & & & & & & & 4,5 & $(0,7)$ \\
\hline Steun (1-4) & 3,2 & $(0,8)$ & 3,1 & $(0,7)$ & 3,2 & $(0,7)$ & 3,2 & $(0,7)$ & 3,4 & $(0,5)$ \\
\hline Conflict (1-3) & 1,4 & $(0,4)$ & 1,5 & $(0,5)$ & 1,6 & $(0,5)$ & 1,6 & $(0,5)$ & 1,3 & $(0,3)$ \\
\hline Partnergeweld (1-3) & 1,1 & $(0,3)$ & 1,2 & $(0,5)$ & 1,3 & $(0,5)$ & 1,2 & $(0,5)$ & $-^{a}$ & \\
\hline Gooien (\% 'ja') & 1,1 & & 13,5 & & 20,0 & & 16,3 & & $-{ }^{a}$ & \\
\hline Duwen (\% 'ja') & 6,7 & & 28,6 & & 34,6 & & 29,4 & & $-^{\mathrm{a}}$ & \\
\hline Slaan / schoppen (\% 'ja') & 4,4 & & 14,8 & & 19,9 & & 16,7 & & $-^{a}$ & \\
\hline $\begin{array}{l}\text { Bedreiging mes / } \\
\text { pistool ( } \% \text { 'ja') }\end{array}$ & 1,1 & & 3,5 & & 4,1 & & 3,4 & & $-{ }^{a}$ & \\
\hline
\end{tabular}

a Informatie over dit partnerkenmerk ontbreekt in de NKPS.

Bron: NKPS, 2005; Prison Project, 2014.

Tabel 7 laat zien dat de relaties van gedetineerden door henzelf als behoorlijk hecht worden geclassificeerd - een gemiddelde score van boven de 4 op een 5-puntsschaal. Vergeleken met de algemene bevolking is de kwaliteit echter minder. Daarnaast wordt er door gedetineerden minder vaak steun ontvangen/ervaren en komen conflicten en ruzies tussen de partners vaker voor. Dit geldt vooral voor de groep eerder gedetineerden. Ook partnergeweld komt onder de groep eerder gedetineerden vaker voor dan bij de gedetineerden die niet eerder gedetineerd zijn geweest. Binnen alle drie de groepen wordt vooral het duwen door de partner gerapporteerd, gevolgd door slaan / schoppen en gooien. Bedreiging met een mes of pistool wordt relatief weinig gerapporteerd.

Voor de relatiekwaliteit, ervaren steun en conflict hebben we eveneens een aantal regressieanalyses uitgevoerd waarbij er wordt gecontroleerd voor individuele achtergrondkenmerken. De resultaten zijn gepresenteerd in tabel 8 en komen in sterke mate overeen met de bevindingen uit de beschrijvende analyses. Er kan geconcludeerd worden dat al voor detentie de relaties van gedetineerden problematischer zijn: ze worden gekenmerkt door een lagere relatiekwaliteit, minder steun en meer conflict. Voor kwaliteit en conflict zijn de effecten het grootst voor de groep die eerder in detentie heeft gezeten. Dit duidt erop dat de ernst van een crimineel verleden van invloed is op de turbulentie van de relatie. Dit zou bijvoorbeeld aan onderliggende persoonlijkheidskenmerken kunnen liggen (zoals zelf- 
controle), maar ook aan de impact van een langere justitiële carrière die een goede relatie in de weg staat.

Tabel 8 Inhoud huidige relatie: regressieanalyses kwaliteit, steun en conflict $(N=3040)^{a}$

\begin{tabular}{|c|c|c|c|c|c|c|}
\hline & \multicolumn{2}{|c|}{ Kwaliteit } & \multicolumn{2}{|c|}{ Steun } & \multicolumn{2}{|c|}{ Conflict } \\
\hline & B & S.E. & B & S.E. & B & S.E. \\
\hline Intercept & $4,60^{* * *}$ & 0,08 & $3,44^{* * *}$ & 0,07 & $1,41^{* * *}$ & 0,04 \\
\hline \multicolumn{7}{|l|}{ Groep (bevolking = ref.) } \\
\hline Nooit eerder contact & $-0,33^{* * *}$ & 0,08 & $-0,19^{* *}$ & 0,06 & 0,07 & 0,04 \\
\hline Eerder justitieel contact & $-0,27^{* * *}$ & 0,07 & $-0,27 * * *$ & 0,05 & $0,20^{* * *}$ & 0,04 \\
\hline Eerder detentie & $-0,42^{* * *}$ & 0,05 & $-0,25 * * *$ & 0,04 & $0,29^{* * *}$ & 0,03 \\
\hline Eerder onbekend & $-0,01$ & 0,13 & 0,08 & 0,11 & 0,06 & 0,06 \\
\hline Leeftijd & $-0,00^{*}$ & 0,00 & $-0,00$ & 0,00 & $-0,00^{* *}$ & 0,00 \\
\hline Allochtoon & 0,09 & 0,05 & $-0,05$ & 0,04 & $-0,06^{*}$ & 0,02 \\
\hline \multicolumn{7}{|c|}{ Opleidingsniveau (laag = ref.) } \\
\hline Midden & $-0,00$ & 0,04 & 0,03 & 0,03 & 0,01 & 0,02 \\
\hline Hoog & $-0,02$ & 0,04 & 0,01 & 0,03 & $0,07^{* * *}$ & 0,02 \\
\hline Betaald werk & 0,07 & 0,04 & 0,05 & 0,03 & $-0,05^{*}$ & 0,02 \\
\hline Kinderen & 0,03 & 0,04 & 0,00 & 0,03 & 0,03 & 0,02 \\
\hline
\end{tabular}

\section{$5 \quad$ Conclusie en discussie}

Hoewel de resultaten van voorgaand onderzoek niet eenduidig zijn, wordt er binnen de levensloopcriminologie verondersteld dat detentie een nadelige invloed heeft op de partnerrelaties van gedetineerden. Om een dergelijk causaal effect te kunnen bevestigen, is er informatie nodig over zowel de situatie vóór, als na detentie. Tot dusverre heeft het eerdere onderzoek zich echter met name gericht op de bestudering van partnerrelaties van gedetineerden in de periode tijdens of na detentie. Over de periode vóór detentie is tot op heden slechts in beperkte mate kennis vergaard. Het doel van de huidige studie was dan ook de kennis over de partnerrelaties van mannelijke gedetineerden in de periode vóór detentie te vergroten. Hiertoe werden niet alleen de partnerrelaties, relatiekwaliteit, relatiegeschiedenis en relatievoorkeuren van gedetineerden beschreven, maar werden zij ook vergeleken met soortgelijke data over de partnerrelaties van mannen uit de algemene Nederlandse bevolking. 
De resultaten in de huidige studie laten een vergelijkbaar beeld zien als de studies die zich concentreren op de periode tijdens of na detentie: gedetineerden hebben relatief instabiele relatiegeschiedenissen en kiezen vaker voor minder traditionele relatievormen. Ook blijkt dat de relaties van gedetineerden in de periode vóór detentie problematischer zijn. Een verklaring voor de waargenomen verschillen in partnerrelaties tussen gedetineerden en de algemene bevolking werd gezocht in mogelijke verschillen in de opbouw van de vergeleken groepen in termen van achtergrondkenmerken (leeftijd, etniciteit, opleidingsniveau, betaalde baan, kinderen). De geobserveerde verschillen bleken slechts ten dele te kunnen worden teruggevoerd op een dergelijk selectie-effect. In lijn met de uitkomsten van eerdere effectstudies bleken de partnerrelaties van recidivisten op veel onderzochte aspecten slechter te zijn. Zowel het stigma dat aan een strafblad en detentie verbonden is, als een opsluitingeffect zouden hier aan ten grondslag kunnen liggen.

De verschillen in partnerrelaties tussen gedetineerden en de algemene bevolking hoeven echter niet per se een selectie- of stigma-effect te weerspiegelen. Mogelijk liggen aan dergelijke verschillen simpelweg verschillen in relatievoorkeuren ten grondslag. Dit bleek echter niet zo te zijn: gedetineerden wilden net zo graag een partnerrelatie of een meer stabiele relatievorm zoals een samenwoonrelatie of huwelijk als mannen uit de algemene bevolking. Deze bevinding is in tegenspraak met de zelfcontroletheorie (Gottfredson \& Hirschi, 1990) die verondersteld dat delinquenten vanwege hun lagere niveau van zelfcontrole minder geneigd zijn om stabiele relaties aan te (willen) gaan. De overeenstemming in voorkeuren lijkt er op te duiden dat bij relatievorming vooral de verminderde mogelijkheden van gedetineerden een rol spelen en niet zozeer een afwijkende voorkeur. Aannemelijk is dat gedetineerden door anderen als minder aantrekkelijke partners worden gezien. Ook zouden zij door een eventuele eerdere detentie simpelweg minder kansen hebben gehad om potentiële partners te ontmoeten en stabiele relaties aan te gaan. Het zou echter ook zo kunnen zijn dat gedetineerden wel een bepaald type relatie willen, maar vanwege persoonlijke eigenschappen geen relatie kunnen vinden of behouden.

Ondanks de meer instabiele relatiegeschiedenissen en de keuze voor minder traditionele relatievormen, waardeerden gedetineerden de kwaliteit van hun eigen partnerrelatie niet veel lager dan mannen uit de algemene bevolking. Een verklaring voor deze onverwachte bevinding zou kunnen worden gezocht in de lagere verwachtingen die gedetineerden hebben over een partnerrelatie, dan wel een geheel ander idee over wat een goede relatie is. Deze verschillen in opvattingen zouden ten dele kun- 
nen worden toegedicht aan de vele (kortdurende) relaties die gedetineerden veelal over de tijd hebben gehad, als ook verschillen in het soort partnerrelaties dat zij in hun sociale omgeving waarnemen.

De resultaten van deze studie dienen niet alleen een wetenschappelijk belang, maar ook een maatschappelijk belang door het aanwezige raakvlak met detentie- en re-integratiebeleid. Hoewel binnen de reclassering de bekende 3 W's (woning, werk en wederhelft) worden onderscheiden, is de focus tot nu toe op de eerste twee - woning en werk - gericht geweest en lijken partnerrelaties daarbij vergeten te zijn. Eerdere studies lieten zien dat stabiele partnerrelaties (met niet-criminele partners) een belangrijke bijdrage leverden aan het verminderen van crimineel gedrag. Meer bewustwording van de impact van partnerrelaties voor recidivekansen is daarom van groot belang. Hoewel relatievorming en partnerkeuze privébeslissingen zijn die lastig zijn te beïnvloeden, bieden de resultaten van deze studie toch een aantal aanknopingspunten voor justitieel beleid. De resultaten laten zien dat de relatie(kansen) van gedetineerden al vóór detentie gemiddeld problematischer zijn dan normaal. Om reeds bestaande relaties in stand te houden en te verbeteren, kan begeleiding en coaching tijdens of na detentie van belang zijn. Om tijdens de periode van detentie de relatie tussen partners zo veel mogelijk te preserveren, kan eveneens worden gedacht aan het stimuleren van bezoekuren en andere vormen van contact gedurende die periode. Initiatieven zoals een relatiebemiddelingsbureau voor gedetineerden - zoals momenteel georganiseerd door Bonjo (www.bonjo.nl) - kunnen daarnaast mogelijk de relatiekansen van gedetineerden bevorderen.

Ondanks de unieke gegevens moet bij het onderzoek ook een aantal kanttekeningen worden geplaatst. Allereerst geldt dat voor beide datasets (Prison Project en NKPS) de gegevens verzameld zijn met behulp van vragenlijsten en interviews. Hoewel het vergeleken met officiële data rijke bronnen van informatie betreft, is een nadeel dat sociaal wenselijke antwoorden en geheugenproblemen de resultaten zouden kunnen vertekenen. Als de vertekening zich bij gedetineerden in dezelfde mate voordoet als bij de algemene bevolking, dan hoeft dit geen probleem te vormen. Het zou echter zo kunnen zijn dat de detentiesituatie een invloed heeft gehad op de antwoorden van de gedetineerden. Hoewel de meeste gedetineerden slechts een aantal weken vastzaten ten tijde van het interview, is het mogelijk dat het terugkijken op de periode voorafgaand aan detentie invloed heeft gehad op de gegeven antwoorden (zie ook Henry, Moffitt, Caspi, Langley \& Silva, 1994). Daarbij geldt ook dat een interview in een gesloten, geïnstitutionaliseerde omgeving aanzienlijk anders is dan een interview in 
een thuissituatie. Een detentieperiode gaat in het algemeen gepaard met onzekerheid en stress. Dit is met name het geval in de eerste weken van de voorlopige hechtenis als het politieonderzoek vaak nog loopt en verdachten in afwachting zijn van de rechtszaak (De Cuyper, Dirkzwager, Völker, Van der Laan, \& Nieuwbeerta, 2012). Terugkijken op de relatief rustige situatie voor detentie zou het oordeel over de partnerrelatie wellicht idealer maken. Tot nu toe is onbekend wat de gevolgen zijn van het houden van interviews in detentie voor de betrouwbaarheid van de data, maar het heeft mogelijk invloed op de beantwoording van de vragen gehad.

Een tweede kanttekening betreft de representativiteit van de data en de generaliseerbaarheid van de resultaten. Hoewel de non-respons bij de NKPS data substantieel was, zorgde de grootte van de steekproef ervoor dat deze toch representatief was voor de Nederlandse bevolking (Dykstra e.a., 2005). In hoeverre de non-respons bij de Prison data een probleem is, kan helaas niet worden vastgesteld omdat er - zo ver wij weten - geen statistieken bekend zijn over de achtergrondkenmerken van de totale populatie gedetineerden in Nederland (op geslacht, leeftijd en geboorteland na). Mogelijk is er wel sprake van een grotere non-respons onder gedetineerden met een relatief slechte partnerrelatie. Omdat een dergelijk selectie-effect echter ook aanwezig is binnen de NKPS, zal de mogelijke selectiviteit een minder grote rol spelen bij de vergelijkingen tussen de twee steekproeven. Hoogst waarschijnlijk heeft de opzet van het Prison Project de generaliseerbaarheid van de data het sterkst beïnvloed. Data zijn namelijk alleen verzameld onder gedetineerden die ten tijde van het interview gedurende drie weken in voorlopige hechtenis zaten, wat betekent dat zij verdacht worden van ernstigere misdrijven. Verder konden gedetineerden met ernstige psychische problemen niet worden benaderd voor het onderzoek. Tot slot zijn uitsluitend mannen in de leeftijd van 18 tot en met 65 jaar die in Nederland geboren zijn meegenomen in het onderzoek. De conclusies van de huidige studie kunnen dan ook alleen worden gegeneraliseerd naar 18 tot 65-jarige mannelijke gedetineerden zonder ernstige psychische problemen.

Een laatste kanttekening moet geplaatst worden bij de vergelijkbaarheid van de data uit het Prison Project en de NKPS. Waar mogelijk hebben we gebruik gemaakt van antwoorden op vragen die identiek waren in beide datasets. En het merendeel van de in deze studie beschreven data was ook zeer vergelijkbaar. Desalniettemin willen we hier benadrukken dat het Prison Project en de NKPS in essentie twee verschillende studies zijn, die door twee verschillende groepen wetenschappers op twee verschillende tijdsmomenten zijn uitgevoerd. We kunnen dus niet volledig uitslui- 
ten dat gevonden verschillen een artefact zijn van verschillen in de opzet van de studie of de formulering van vraagstellingen.

Deze studie levert belangrijke aanknopingspunten op voor vervolgonderzoek. Allereerst is noodzakelijk dat studies naar de effecten van detentie op partnerrelaties goed rekening houden met relatiekenmerken voor detentie. Gedetineerden en niet-gedetineerden blijken al voor detentie van elkaar te verschillen. Alleen door pre-detentie kenmerken mee te nemen kan daadwerkelijk worden vastgesteld in hoeverre er een effect is van detentie op relatie(kansen). Verder is in deze studie een voorzet gedaan voor de mechanismen die mogelijk een rol kunnen spelen bij de relatie tussen detentie en partnerrelaties. Toekomstige studies zouden zich moeten richten op het ontrafelen van de verschillende mechanismen die hier aan ten grondslag kunnen liggen. Wat is de relatieve rol van voorkeuren versus mogelijkheden bij relatievorming, partnerkeuze en relatieontbinding? In hoeverre is detentie van invloed op de inhoud van de relatie (kwaliteit, conflicten, partnergeweld)? In welke mate kunnen zelfcontrole, stigma en incapacitatie daarbij als onderliggende verklaringen dienen? Kwalitatieve diepte-interviews met gedetineerden zouden een goede aanvulling kunnen vormen op de bestaande kwantitatieve data. Op deze manier kan meer inzicht worden verkregen in eventuele problemen op relatiegebied in de periode voorafgaand, gedurende en na detentie.

\section{Noten}

1. Dit artikel is gebaseerd op data van het Prison Project en de Netherlands Kinship Panel Study (NKPS). Het Prison Project is gefinancierd door de Universiteit Leiden, het Nederlands Studiecentrum voor Criminaliteit en Rechtshandhaving (NSCR), de Nederlandse Organisatie voor Wetenschappelijk Onderzoek (NWO) en de Universiteit Utrecht. De NKPS is gefinancierd door de Nederlandse Organisatie voor Wetenschappelijk Onderzoek (NWO, 480-10-0o9), het Nederlands Interdisciplinair Demografisch Instituut (NIDI), de Universiteit Utrecht, de Universiteit van Amsterdam en de Universiteit van Tilburg.

2. Gedetineerden die in voorlopige hechtenis zitten worden verdacht van het plegen van een (ernstig) misdrijf en zijn in afwachting van hun rechtszaak. Hoewel zij verdacht worden van het plegen van een delict en niet per definitie schuldig zijn, blijkt dat in Nederland het overgrote deel $(90,4 \%)$ van de verdachten uiteindelijk door de rechter schuldig wordt verklaard (Kalidien, De Heer-de Lange \& Van Rosmalen, 2011).

3. Dit onderscheid is gebaseerd op het zelfgerapporteerde justitiële verleden van de respondent.

4. De uiteindelijke steekproef van gedetineerden komt uit op 1753 mannen. Dit aantal is lager dan de oorspronkelijke 1909 mannen, omdat voor 156 mannen informatie over de gerapporteerde achtergrondkenmerken in tabel 1 ontbrak. 
5. Hoewel de gebruikte items voor het meten van relatiekwaliteit verschilden in de NKPS en Prison sample, is er sprake van een grote overlap in de aspecten waarnaar gevraagd is (stabiliteit, geluk). Bovendien is de correlatie met de overige relatie-inhoudelijke variabelen vrijwel gelijk in de Prison en NKPS data (respectievelijk .43 en $.5^{2}$ voor de correlatie met steun en -.46 en -.44 voor de correlatie met conflict), hetgeen ons doet vermoeden dat een soortgelijk aspect van de relatie wordt gemeten.

6. In de analyses waarin 'partners waarvan kinderen' de afhankelijke variabele vormt, is 'het hebben van kinderen' niet als controlevariabele meegenomen. De resultaten van deze regressieanalyses zijn echter niet weergegeven in tabel 3 aangezien het niet de kern van dit artikel betreft en gezien de omvang van de tabel. De resultaten komen echter overeen met de beschrijvende analyses: gedetineerden hebben minder vaak eerdere partner(s) gehad waarvan zijn kinderen hebben, maar hebben gemiddeld meer kinderen bij eerdere partner(s) als dit wel het geval is.

7. Een marginaal effect geeft de verandering in de kans weer als de desbetreffende onafhankelijke variabele met 1 unit zou veranderen. Het marginale effect van een dummyvariabele is bijvoorbeeld het verschil tussen het deel uitmaken van categorie o versus categorie 1 (zoals geen allochtoon versus wel allochtoon). Per onafhankelijke variabele in de tabel tellen de marginale effecten horizontaal op tot 1.

8. De Prison data geven eveneens inzicht in de gelegenheid waar partners elkaar ontmoet hebben. Het blijkt dat gedetineerden elkaar relatief vaak ontmoeten op feestjes en via uitgaan en minder vaak via opleiding of werk. Verder komt naar voren dat 1,5 procent elkaar in de gevangenis heeft ontmoet. Detentie beperkt dus niet geheel de mogelijkheden tot relatievorming.

\section{Literatuur}

Apel, R., Blokland, A.A.J., Nieuwbeerta, P. \& Schellen, M. van (2010). The impact of first-time imprisonment on marriage and divorce: A matched samples comparison in a Dutch conviction cohort. Journal of Quantitative Criminology, 26, 269-300.

Baaren, J. van \& Son, S. van (1984). Relaties van gedetineerden. Eindscriptie. Culemborg: Sociale Academie de Neijenburgh.

Bersani, B.E., Laub, J.H. \& Nieuwbeerta, P. (2009). Marriage and desistance from crime in the Netherlands: Do gender and socio-historical context matter? Journal of Quantitative Criminology, 25, 3-24.

Braman, D. (2004). Doing time on the outside: Incarceration and family life in urban America. University of Michigan Press.

Comfort, M. (2008). Doing time together: Love and family in the shadow of the prison. Chicago: University of Chicago Press.

Cuyper, R. de, Dirkzwager A.J.E., Völker, B., Laan, P.H. van der \& Nieuwbeerta, P. (2012). Het sociale netwerk voorafgaand aan detentie. Een vergelijking tussen gedetineerden en de $\mathrm{Ne}$ derlandse bevolking. Mens \& Maatschappij, 87, 245-271.

Dienst Justitiële Inrichtingen (2013). http://www.dji.nl/Organisatie/Feiten-en-cijfers/.

Dirkzwager, A.J.E., Nieuwbeerta, P. \& Fiselier, J.P.S. (2009). Onbedoelde gevolgen van vrijheidsstraffen: Een literatuurstudie. Tijdschrift voor Criminologie, 51, 21-41.

Dykstra, P.A., Kalmijn, M., Knijn, T.C.M., Komter, A.E., Liefbroer, A.C. \& Mulder, C.H. (2005). Codebook of the Netherlands Kinship Panel Study, Wave 1. 
Giordano, P.C., Cernkovich, S.A. \& Rudolph, J. L. (2002). Gender, crime, and desistance: Toward a theory of cognitive transformation. American Journal of Sociology, 107, 990-1064.

Gottfredson, M.R. \& Hirschi, T. (1990). A general theory of crime. Stanford: Stanford University Press.

Harman J.J., Smith, V.E. \& Egan, L.C. (2007). The impact of incarceration on intimate relationships. Criminal Justice and Behavior, 34, 794-815.

Henry, B., Moffitt, T.E., Caspi, A., Langley, J. \& Silva, P.A. (1994). On the "remembrance of things past": A longitudinal evaluation of the retrospective method. Psychological Assessment, 6, 92101.

Hirschi, T. \& Gottfredson, M.R. (1995). Control theory and the life-course perspective. Studies on Crime and Crime Prevention, 4, 131-142.

Huebner, B.M. (2005). The effect of incarceration on marriage and work over the life course. Justice Quarterly, 22, 281-303.

Huebner, B.M. (2007). Racial and ethnic differences in the likelihood of marriage: The effect of incarceration. Justice Quarterly, 24, 156-183.

Janssen, J.H.L.J (1999). Laat maar zitten: Een exploratief onderzoek naar de werking van de korte vrijheidsstraf. Rijksuniversiteit Groningen.

Johnson, B.D., Wingerden, S. van \& Nieuwbeerta, P. (2010). Sentencing homicide offenders in the Netherlands: Offender, victim and situational influences in criminal punishment. Criminology, 48, 981-1018.

Kalidien, S.N., Heer-de Lange, N.E. de \& Rosmalen, M.M. van (2011). Criminaliteit \& rechtshandhaving 2010. Ontwikkelingen en samenhangen. Den Haag: WODC, Ministerie van Justitie.

Laub, J.H. \& Sampson, R.J. (2003). Shared beginnings, divergent lives: Delinquent boys to age 70. Cambridge: Harvard University Press.

Linckens, P. \& Looff, J. de (2011). Gevangeniswezen in getal, 20o6-2010. Ministerie van Justitie, Dienst Justitiële Instellingen.

London, A.S. \& Parker W.M. (2009). Incarceration and living arrangements: Findings from the National Health and Social Life Survey. Journal of Family Issues, 30, 787-812.

Lopoo, L.M. \& Western, B. (2005). Incarceration and the formation and stability of marital unions. Journal of Marriage and Family, 67, 721-734.

Moerings, M. (1978). De gevangenis uit, de maatschappij in. De gevangenisstraf en haar betekenis voor de sociale contacten van ex-gedetineerde. Alphen aan den Rijn: Samson Uitgeverij.

Pager, D. (2003). The mark of a criminal record. American Journal of Sociology, 108, 937-975.

Ramakers, A., Wilsem, J. van, Nieuwbeerta, P. \& Dirkzwager, A.J.E. (2012). Het arbeidsverleden van gedetineerden voorafgaand aan detentie. Een vergelijking tussen gedetineerden en de algemene bevolking. Mens \& Maatschappij, 87, 272-301.

Royston, P. (2007). Multiple imputation of missing values: Further update of ICE, with an emphasis on interval censoring. The Stata Journal, 7, 445-464.

Sampson, R.J. \& Laub, J.H. (1993). Crime in the making. Pathways and turning points through life. Cambridge: Harvard University Press.

Sampson, R.J., Laub, J.H. \& Wimer, C. (2006). Does marriage reduce crime? A counterfactual approach to within-individual causal effects. Criminology, 44, 465-508.

Schellen, M. van (2012). Marriage and crime over the life course. The criminal careers of convicts and their spouses. Dissertatie: Universiteit Utrecht.

Simons, R.L., Stewart, E., Gordon, L.C., Conger, R.D., \& Elder Jr, G.H. (2002). A test of life course explanations for stability and change in antisocial behavior from adolescence to young adulthood. Criminology, 40, 401-33.

Spruijt, E. \& Kormos, H. (2010). Handboek scheiden en de kinderen. Bohn Stafleu van Loghum. 
Verbruggen, J., Apel, R., Geest, V. van der \& Blokland, A. (2013). Werk, uitkeringen en criminaliteit. Kwetsbare jongeren gevolgd van 18 tot 32 jaar. Mens en Maatschappij, 88, 253-275.

Warr, M. (1998). Life-course transitions and desistance from crime. Criminology, 36, 183-215.

Western, B. (2006). Punishment and inequality in America. New York: Russell Sage Foundation.

Western, B. \& McLanahan, S. (200o). Fathers behind bars: the impact of incarceration on family formation. In G. Litton Fox \& M.L. Benson (red.), Families, crime and criminal justice: Contemporary perspectives in family research, volume 2 (pp. 309-324). New York: Elsevier Science.

Western, B., Lopoo, L. M. \& McLanahan, S. (2004). Incarceration and the bonds among parents in fragile families. In M. Patillo, D. Weiman \& B. Western (red.), Imprisoning America: The social effects of mass incarceration (pp. 21-45). New York: Russell Sage Foundation.

\section{Over de auteurs}

Marieke van Schellen en Tanja van der Lippe zijn respectievelijk als postdoc en hoogleraar verbonden aan de vakgroep Sociologie/ICS van de Universiteit Utrecht.

Martijn Hogerbrugge is als onderzoeker werkzaam bij het Wales Institute of Social and Economic Research, Data and Methods (WISERD) aan Cardiff University.

Paul Nieuwbeerta is als hoogleraar verbonden aan het Instituut voor Strafrecht en Criminologie van de Universiteit Leiden.

Anja Dirkzwager is als senior onderzoeker werkzaam bij het Nederlands Studiecentrum voor Criminaliteit en Rechtshandhaving (NSCR) te Amsterdam. 